\title{
Degradation of Diclofenac in Urine by Electro-Permanganate Process Driven by Microbial Fuel Cells
}

\author{
Xuxu Wang ${ }^{1,+}+\mathbb{D}$, Ying Wang ${ }^{1,+}{ }^{\text {, Jian Zhang }}{ }^{2}$, Pengbo Duanmu ${ }^{3}$, Liushi Zheng ${ }^{1}$, Shabi UI Hasson ${ }^{1}$, \\ Andrew Baldwin ${ }^{1}$, Irene Wong ${ }^{4}$ and Chun Zhao ${ }^{1,2, *}$ \\ 1 National Centre for International Research of Low-carbon and Green Buildings, Chongqing University, \\ Chongqing 400045, China; m13308375047@163.com (X.W.); 20191713077t@cqu.edu.cn (Y.W.); \\ zls521003@163.com (L.Z.); shabihassanqureshi@gmail.com (S.U.H.); A.N.Baldwin@iboro.ac.uk (A.B.) \\ 2 School of Water Conservancy and Architectural Engineering, Shihezi University, Shihezi 832003, China; \\ fluorite.j.zhang@hotmail.com \\ 3 School of Civil Engineering and Architecture, Zhongyuan University of Technology, \\ Zhengzhou 450007, China; 2018109145@zut.edu.cn \\ 4 Department of Civil and Environmental Engineering, The Hong Kong Polytechnic University, \\ Hong Kong, China; irene.w@connect.polyu.hk \\ * Correspondence: pureson@163.com; Tel.: +86-188-750-38854 \\ + These authors contributed equally to this work and should be considered co-first authors.
}

\section{check for} updates

Citation: Wang, X.; Wang, Y.; Zhang, J.; Duanmu, P.; Zheng, L.; Hasson, S.U.; Baldwin, A.; Wong, I.; Zhao, C. Degradation of Diclofenac in Urine by Electro-Permanganate Process Driven by Microbial Fuel Cells. Water 2021, 13, 2047. https://doi.org/10.3390/ w13152047

Academic Editors: Jiangyong Hu, Say Leong Ong, Wenjun Sun and Weiling Sun

Received: 28 June 2021

Accepted: 22 July 2021

Published: 27 July 2021

Publisher's Note: MDPI stays neutral with regard to jurisdictional claims in published maps and institutional affiliations.

Copyright: (c) 2021 by the authors. Licensee MDPI, Basel, Switzerland. This article is an open access article distributed under the terms and conditions of the Creative Commons Attribution (CC BY) license (https:// creativecommons.org/licenses/by/ $4.0 /)$.

\begin{abstract}
A novel microbial fuel cell-assisted electro-permanganate process (MFC-PM) was proposed for enhanced diclofenac degradation compared to that of the permanganate oxidation process. By utilizing eco-friendly bio-electricity in situ, the MFC-PM process could activate the simultaneous anodic biological metabolism of urea and the cathodic electro-permanganate process. Density functional analysis and experimental evidence revealed the reactive manganese species $\left(\mathrm{Mn}(\mathrm{VII})_{\mathrm{aq}}, \mathrm{Mn}(\mathrm{VI})_{\mathrm{aq}}\right.$, $\mathrm{Mn}(\mathrm{V})_{\mathrm{aq}}$, and $\left.\mathrm{Mn}(\mathrm{III})_{\mathrm{aq}}\right)$, generated via single electron transfer, contributed to diclofenac degradation in the cathodic chamber. The sites of diclofenac with a high Fukui index were preferable to be attacked by reactive manganese species, and diclofenac degradation was mainly accomplished through the ring hydroxylation, ring opening, and decarboxylation processes. Biological detection revealed clostridia were the primary electron donor in the anode chamber in an anaerobic environment. Furthermore, maximum output power density of $1.49 \mathrm{~W} \mathrm{~m}^{-3}$ and the optimal removal of $94.75 \%$ diclofenac were obtained within $20 \mathrm{~min}$ under the conditions of $\mathrm{pH}=3.0,[\mathrm{DCF}]_{0}=60 \mu \mathrm{M}$, and $[\mathrm{PM}]_{0}=30 \mu \mathrm{M}$. Diclofenac removal efficiency increased with external resistance, higher PM dosage, and lower catholyte $\mathrm{pH}$. In addition, the MFC-PM process displayed excellent applicability in urine and other background substances. The MFC-PM process provided an efficient and energy-free bio-electricity catalytic permanganate oxidation technology for enhancing diclofenac degradation.
\end{abstract}

Keywords: microbial fuel cells; electro-permanganate; reactive manganese species; urine treatment

\section{Introduction}

Pharmaceutical and personal care products (PPCPs) are an emerging class of pollutants in water that have received widespread and sustained attention [1]. Diclofenac sodium (DCF, a typical PPCP) has anti-inflammatory, anti-rheumatic, analgesic, and antipyretic effects. It is widely utilized to treat arthritis symptoms, rheumatism, gout, various fevers, trauma or post-operative pain, and gynecological pain. Global annual demand for DCF is more than 4000 tons, and annual per capita consumption ranges between 195-940 mg [2-5]. Nevertheless, only a small portion of DCF is absorbed by humans and animals; more than $65 \%$ of DCF is excreted in urine or feces as parent drug or metabolite [6,7]. Traditional treatment methods (i.e., activated sludge method in wastewater treatment plants (WWTPs)) display low DCF removal efficiency due to the bio-refractory nature of DCF [8]. Undegraded DCF enters rivers, lakes, plants, and animals through the water cycle and food

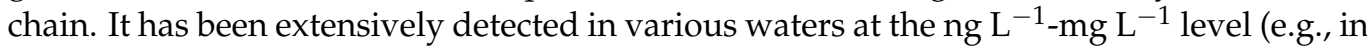


sewage treatment plant tailwater, drinking water, surface water, and human urine) [8-10]. Due to its potential physiological toxicity, DCF in water poses a huge threat to human beings and the environment [9]. Therefore, there has been an urgent need to develop effective strategies for DCF removal.

In recent years, advanced oxidation processes (e.g., Fenton technology [11], Fenton-like technology [12], ozone oxidation technology [13], permanganate oxidation technology [14], and photocatalytic technology [15]) have attracted considerable attention from researchers as methods for the degradation of such bio-refractory organic pollutants. In particular, permanganate oxidation technology has been widely utilized for the elimination of organic pollutants due to its advantages as a low-cost, easily transportable, and environmentally friendly methodology [16]. However, the stability of permanganate $\left(P M, E^{0}=1.68 \mathrm{eV}\right)$ and its low potential relative to radicals [17] to a certain extent limit its reactivity to organic pollutants. To expand the availability of PM, many researchers have focused considerable attention on the search for an effective means of activating PM. Highly reactive manganese species (RMnS), such as $\mathrm{Mn}(\mathrm{VI}), \mathrm{Mn}(\mathrm{V}), \mathrm{Mn}(\mathrm{III})$, and reactive oxygen species (e.g., $\bullet^{\bullet} \mathrm{OH}$ and $\mathrm{SO}_{4}{ }^{\bullet-}$ ), are generated by the rapid oxidation of pollutants $[18,19]$. Ultraviolet (UV) irradiation, biochar, and some reagents (e.g., bisulfite and humic acid (HA)) have been successfully applied to activate PM. The formed reactive species can accelerate the oxidation rate of PM [20-23]. Our previous work also proved that PM could be reduced to RMnS in an electric field (E-PM), and that the generated RMnS was faster than PM in the oxidation of DCF $[17,24,25]$. Compared to other methods, the controlled and eco-friendly electrical activation method provided a novel strategy for PM activation; however, the energy consumption issues and manganese transformation mechanism during the E-PM reaction process needed to be further addressed.

Microbial fuel cells (MFCs) are generally considered as green energy transducers, which can turn chemical energy into electrical energy (bio-electricity) via the metabolism of microorganisms in an anode chamber [26]. Due to the non-negligible energy losses in the conversion and storage process, many scholars prefer to utilize the bio-electricity in-situ in the cathode chamber [27-29]. Previous works proved that bio-electricity produced via MFCs is an effective energy that can catalyze oxygen, persulfate, and hydrogen peroxide $\left(\mathrm{H}_{2} \mathrm{O}_{2}\right)$ to produce active species (e.g., ${ }^{\bullet} \mathrm{OH}$ and $\mathrm{SO}_{4}{ }^{\bullet-}$ ) (Equations (1)-(4) [30-32]) for accelerating the removal of organic contaminants in situ in the cathode chamber [33,34]. Moreover, photocatalytic oxidation technology combined with bio-electricity was also utilized to removal contaminants in the cathode chamber [27,35]. Hence, in the E-PM process, bio-electricity might also replace traditional power to catalyze PM in situ for enhancing the degradation of organic contaminants in the cathode chamber via the generation of active species. The replacement of conventional electricity by bio-electricity could also significantly reduce the energy consumed by the E-PM process in pollutant removal.

$$
\begin{gathered}
2 \mathrm{H}^{+}+2 \mathrm{e}^{-}+\mathrm{O}_{2} \rightarrow \mathrm{H}_{2} \mathrm{O}_{2} \\
\mathrm{Fe}(\mathrm{II})+\mathrm{H}_{2} \mathrm{O}_{2} \rightarrow \mathrm{Fe}(\mathrm{III})+\mathrm{HO}^{-}+\mathrm{HO}^{\bullet} \\
\mathrm{HSO}_{5}{ }^{-}+\mathrm{e}^{-} \rightarrow \mathrm{HO}^{-}+\mathrm{SO}_{4}{ }^{\bullet-} \\
\mathrm{HSO}_{5}{ }^{-}+\mathrm{e}^{-} \rightarrow \mathrm{HO}^{\bullet}+\mathrm{SO}_{4}{ }^{2-}
\end{gathered}
$$

Herein, a novel two-chamber MFC, coupling an MFC system with the E-PM process (MFC-PM), was constructed to activate PM for DCF removal. At first, the removal ratio and degradation kinetics of DCF were investigated under different operational conditions (PM dosage, catholyte $\mathrm{pH}$, and external resistance) to exploit the removal efficiency of the MFC-PM process. Then, the primary electricity-producing bacteria in the anode chamber, the reaction mechanism in the cathode chamber, and the degradation pathway of DCF were explained. At a minimum, the potential applicability of the MFC-PM process was tested. 


\section{Materials and Methods}

2.1. Materials and Reagents

All reagents were analytic reagent grade or higher and used as received. DCF purchased from the Micxy Chemical Co., Ltd, Cheng Du, China as the sodium salt, was used as the target pollutant in this study. Potassium permanganate (GR grade), acetic acid, methanol, and acetonitrile were chromatographic grade. In addition, HA was purchased from Sigma-Aldrich Chemical Co., Ltd, Darmstadt, Germany. The methanol (MA, 99.9\%) and acetonitrile (ACN, 99.9\%) were obtained in HPLC grade from CINC High Purity Solvents (Shanghai) Co., Ltd. Phenol $\left(\mathrm{C}_{6} \mathrm{H}_{6} \mathrm{O}, 99 \%\right.$ ), tert-butanol (TBA, $\mathrm{C}_{4} \mathrm{H}_{10} \mathrm{O}$, purity $99.0 \%$ ), formic acid (HPLC grade), acetic acid (HPLC grade), anhydrous sodium sulfate $\left(\mathrm{Na}_{2} \mathrm{SO}_{4}\right.$, $99.0 \%)$, sodium bicarbonate $\left(\mathrm{NaCO}_{3}, 99.8 \%\right)$, sodium chloride $(\mathrm{NaCl}, 98.0 \%)$, and sodium nitrite $\left(\mathrm{NaNO}_{3}, 99.0 \%\right)$ were obtained from Kelong Chemical Co., Ltd, Chengdu, China. Sulfuric acid $\left(\mathrm{H}_{2} \mathrm{SO}_{4}, 98.0 \%\right)$, sodium hydroxide $(\mathrm{NaOH}$, purity $98.0 \%)$, hydroxylammonium chloride $\left(\mathrm{NH}_{2} \mathrm{OH} \cdot \mathrm{HCl}, 98 \%\right)$, and sodium pyrophosphate decahydrate $\left(\mathrm{Na}_{4} \mathrm{P}_{2} \mathrm{O}_{7} \cdot 10 \mathrm{H}_{2} \mathrm{O}\right.$, 99\%) were obtained from Chuandong Chemical Co., Ltd, Chongqing, China. All sample solutions and the mobile phase were prepared with ultrapure water $(18.2 \mathrm{M} \Omega \mathrm{cm})$.

\subsection{Reactor and Operation}

The anode chamber solution contained the following nutrients: $\mathrm{CO}\left(\mathrm{NH}_{2}\right)_{2} 39.64 \mathrm{~g} \mathrm{~L}^{-1}$, $\mathrm{KCl} 0.26 \mathrm{~g} \mathrm{~L}^{-1}, \mathrm{NH}_{4} \mathrm{Cl} 0.62 \mathrm{~g} \mathrm{~L}^{-1}, \mathrm{NaH}_{2} \mathrm{PO}_{4} \cdot 2 \mathrm{H}_{2} \mathrm{O} 5.54 \mathrm{~g} \mathrm{~L}^{-1}, \mathrm{Na}_{2} \mathrm{HPO}_{4} \cdot 12 \mathrm{H}_{2} \mathrm{O} 23.1 \mathrm{~g} \mathrm{~L}^{-1}$, and trace elements displayed in Tables S1 and S2. The catholyte was $\mathrm{Na}_{2} \mathrm{SO}_{4}(0.05 \mathrm{M})$ and $\mathrm{PM}$. Initial $\mathrm{pH}$ values were adjusted by $\mathrm{HCl}$ (anolyte), $\mathrm{H}_{2} \mathrm{SO}_{4}$ (catholyte), and $\mathrm{NaOH}$.

The reactor in this study was divided by a proton exchange membrane (Nafion 117, DuPont Co., Ltd., Wilmington, NC, USA). Pt electrode plating on the Ti flat $\left(60 \times 70 \times 1 \mathrm{~mm}^{3}\right)$ was utilized in the cathode chamber, and a carbon brush electrode $\left(50 \times 60 \times 150 \mathrm{~mm}^{3}\right)$ was placed in the anode chamber. The volumes of both the anode and cathode chamber were $0.51 \mathrm{~L}$. Sequencing batch mode was utilized in the operation of the MFC-PM process. Before each test, the catholyte was purged with nitrogen to remove oxygen. After the end of each cycle, the catholyte was replaced, and hydroxylamine hydrochloride was utilized to remove the $\mathrm{MnO}_{\mathrm{x}}(\mathrm{x}=1-2)$, which could be deposited on the surface of the electrode.

In the first 3 operating cycles, the completion of the start-up of the MFC was assumed when the output voltage differed by less than $5 \%$. The activated sludge sample was taken from the secondary sedimentation tank of a sewage plant and incubated for 30 days in a domesticated form. An experiment started when the voltage was stable ( $>0.8 \mathrm{~V})$; after each experiment, the voltage continued to be monitored until it was stable again, then the next experiment was started. When the voltage dropped to less than $0.6 \mathrm{~V}$, the medium in the anode chamber after the reaction was replaced with fresh medium (see Figure S1a).

\subsection{Analytical Methods}

Samples collected from the cathode chamber were immediately filtered through a $0.22 \mu \mathrm{m}$ filter and quenched with $100 \mu \mathrm{L}$ hydroxylamine hydrochloride $(0.01 \mathrm{M})$. The DCF concentration was determined by HPLC-UV (Waters ${ }^{\circledR}$, Milford, MA, USA) with a COSMOSIL 3C18-MS-II column $(5 \mu \mathrm{m}$ particle size, $4.6 \times 150 \mathrm{~mm}$, Nacalai Tesque, Inc., Kyoto, Japan), and a UV-Visible detector (Waters ${ }^{\circledR} 2487$ ) at a wavelength of $276 \mathrm{~nm}$ with a flow rate of $0.8 \mathrm{~mL} \mathrm{~min}-1$. The mobile phase was composed of $3 \%$ acetic acid and acetonitrile (20: 80, $v / v)$. The PM concentration was measured by the ABTS method at $415 \mathrm{~nm}$ [36]. The intermediate products in DCF degradation were determined by UPLCIMS-QTOF-MS (Waters ${ }^{\circledR}$, Milford, MA, USA) with a Column-BEH C18 $(2.1 \times 100 \mathrm{~mm}$, $1.7 \mu \mathrm{m}$ ). The eluent consisted of two mobile phases at $0.2 \mathrm{~mL} \mathrm{~min}^{-1}$ : (A) $0.1 \%$ formic acid in water $(v / v)$, and (B) $0.1 \%$ methanol. The gradient was as follows: (i) $50 \%$ component (A), and 50\% component (B) was maintained during the first $10 \mathrm{~min}$; (ii) component (A) was decreased from $50 \%$ to $25 \%$ in the next $10 \mathrm{~min}$, and component (B) was maintained at $75 \%$; (iii) component (A) and component B were both maintained at $50 \%$ for $20 \mathrm{~min}$. Mass spectrometric analysis was conducted using positive/negative electrospray ionization with 
a mass scan range of $m / z$ 50-1000. The DCF removal ratio and PM consumption ratio were calculated as \% with Equations (5) and (6), respectively. The generation of RMnS and the UV-vis spectral changes of the solution were monitored by UV-vis spectrophotometers (T6, Purkinje Co., Beijing, China).

$$
\begin{gathered}
\text { Degradation }(\%)=\left(C_{0}-C_{t}\right) / C_{0} \times 100 \% \\
\text { Consumption }(\%)=\left(C(P M)_{0}-C(P M)_{t}\right) / C(P M)_{0} \times 100 \%
\end{gathered}
$$

where $\mathrm{C}_{0}$ and $\mathrm{C}(\mathrm{PM})_{0}$ were the DCF concentration $(\mu \mathrm{M})$ and the total PM concentration $(\mu \mathrm{M})$ in the initial solution, and $C_{t}$ and $C(P M)_{t}$ were the corresponding values at time.

\subsection{Electrochemical Measurements and Microbial Characterization}

Cyclic voltammetry (CV) was performed using an electrochemical workstation (CHI660E, Chenhua) with a 3-electrode mode. The $\mathrm{Ag} / \mathrm{AgCl}$ electrode was utilized as a reference electrode placed in the anode chamber. Connected to a $1000 \Omega$ external resistor, the voltage outputs were monitored by a data collector (RS232/485, China) every 0.5 min. Power density curves and polarization of the MFC process were obtained by varying the external resistance from 9999 to $9 \Omega$, when the voltage output approached steady state. The current density I was calculated as $\mathrm{I}=\mathrm{U} /(\mathrm{R} \times \mathrm{A})$, and the power was calculated as $\mathrm{P}=\mathrm{U} \times \mathrm{I}$.

The microbial layered on the carbon brush electrodes was collected, centrifuged, and concentrated in a $5 \mathrm{~mL}$ centrifuge tube, then stored in liquid nitrogen. The integrity of the extracted DNA was inspected by $1 \%$ agarose gel electrophoresis. The amplified DNA was analyzed with an Illumina MiSeq high-throughput sequencer supported by Shanghai Meiji Biotechnology Co., Ltd. Samples were stored in liquid nitrogen before PCR amplification, and the microbial community structures of carbon brush were detected by $16 \mathrm{~s}$ rRNA pyrosequencing. The primer pair were 515F (5'-GTGCCAGCMGCCGCGG-3') and 907R(5'-CCGTCAATTCMTTTRAGTTT-3' $)$, respectively. Moreover, the F-terminal sequence and R-terminal sequence were GTGYCAGCMGCCGCGGTAA and GGACTACNVGGGTWTCTAAT, respectively.

\subsection{Model Construction and Density Functional Theory Calculations}

In this paper, a $2 \times 2$ supercell of platinum crystal with 4 layers was constructed. A $15 \AA$ A vacuum space was established along the $\mathrm{Pt}(111)$ crystal plane, which could minimize the inter-reaction between adjacent boxes. The monomer models of $\mathrm{Mn}(\mathrm{VII}), \mathrm{Mn}(\mathrm{VI})$, $\mathrm{Mn}(\mathrm{V})$, and $\mathrm{Mn}(\mathrm{III})$ were constructed via the reference [36]. In addition, the structural optimization and adsorption energy calculation were performed with Material Studio Software via the generalized gradient approximation (GGA) in the form of the PerdewBurke-Ernzerhof (PBE) function. During the calculations, the Monkhorst-Pack $2 \times 2 \times 1$ $k$-pointing mesh with $400 \mathrm{eV}$ cutoff energy was utilized. All calculations were accepted when the threshold was $<10^{-5} \mathrm{eV}$ in energy, and the force was $<0.03 \mathrm{eV} \AA^{-1}$. DFT-D corrections were utilized to evaluate non-covalent forces through the Grimme scheme. The adsorption energy $\left(\mathrm{E}_{\mathrm{ads}}\right)$ of substances on the plane was calculated with Equation (7).

$$
E_{\mathrm{ads}}=\mathrm{E}_{\mathrm{Pt}+\mathrm{sub}}-\mathrm{E}_{\mathrm{Pt}}-\mathrm{E}_{\mathrm{Sub}}
$$

where $\mathrm{E}_{\mathrm{Pt}+\mathrm{sub}}, \mathrm{E}_{\mathrm{Pt}}$, and $\mathrm{E}_{\mathrm{sub}}$ were the energy of Pt and substances, Pt crystal, and substances, respectively.

\section{Results}

\subsection{DCF Removal in the Cathode Chamber}

DCF removal in the PM oxidation process, the bio-electricity process (i.e., Pt-plating titanium in cathode chamber without PM), and the MFC-PM process (i.e., Pt-plating titanium in cathode chamber with PM) were evaluated. As displayed in Figure 1a, after 20 min reaction, the average removal of DCF was $80.26 \%$ in the PM oxidation process, 
whereas those for the MFC-E process and MFC-PM process were $12.63 \%$ and $94.75 \%$, respectively. DCF removal efficiency of the MFC-PM process was faster than the others. Furthermore, the kinetic parameters of the rate constants were calculated and summarized in Figure 1b. As displayed in Figure 1b, the removal rates of DCF in all processes followed pseudo-first-order kinetics. The reaction rate constants $(k)$ of the bio-electricity oxidation, PM oxidation, and MFC-PM processes were $0.009,0.073$, and $0.155 \mathrm{~min}^{-1}$, respectively. PM consumption in the PM oxidation process and MFC-PM process were also observed. As shown in Figure 1c, in the PM oxidation process, $89.86 \%$ of PM was consumed within $20 \mathrm{~min}$, while $93.43 \%$ of PM was consumed in the MFC-PM process. Additionally, the DCF removal efficiency of the MFC-PM process compared to other systems was evaluated and listed in Table S3. As illustrated in Table S3, the DCF removal efficiency of the MFC-PM process was higher than most other existing processes, indicating that DCF could be rapidly removed by the MFC-PM process.
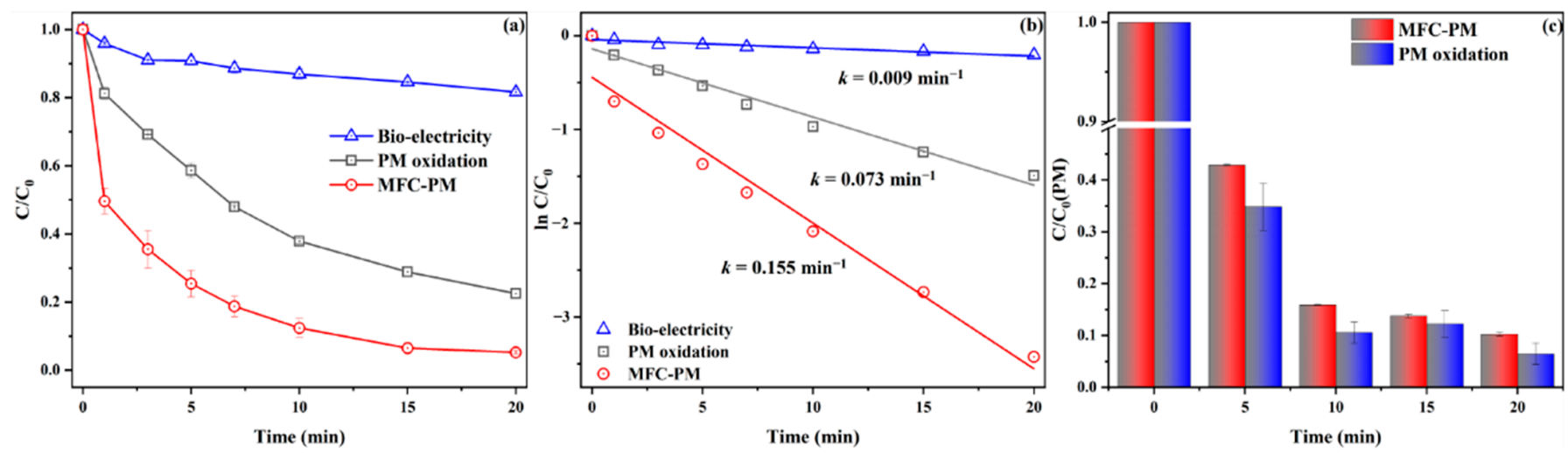

Figure 1. The removal ratio of DCF (a), DCF degradation kinetics (b), and PM consumption (c) by the PM, MFC-E, and MFC-PM processes $\left(\mathrm{pH}=3.0 ;[\mathrm{DCF}]_{0}=60 \mu \mathrm{M}\right.$; external resistance $\left.=0 \Omega ;[\mathrm{PM}]_{0}=30 \mu \mathrm{M}\right)$.

The higher DCF removal rate achieved with the MFC-PM process could be attributed to the oxidation of DCF by PM and the highly active species formed by the combination of PM and bio-electricity. As displayed in Figure 1, compared to the PM oxidation process, DCF removal, reaction rate constants, and PM consumption in the MFC-PM process were all increased significantly, which indicated that PM was activated with the employment of bio-electricity. These results also demonstrated a synergistic effect between PM oxidation and bio-electricity. The synergistic index (Equation (8)) was calculated to be $1.9(>1)$, which also indicated a synergetic effect between the PM and bio-electricity processes [22].

$$
\text { Synergistic index }=k(\mathrm{MFC}-\mathrm{PM}) /(k(\mathrm{PM})+k(\text { bio-electricity })
$$

where $k(\mathrm{MFC}-\mathrm{PM}), k(\mathrm{PM})$, and $k$ (bio-electricity) were the pseudo-first-order rate constants of the MFC-PM, PM, and bio-electricity processes, respectively $\left(\mathrm{min}^{-1}\right)$.

\subsection{Process Optimization \\ 3.2.1. Effect of PM Dosages}

As shown in Figure 2 and Table S4, with the increase of PM dosages (from 15 to $45 \mu \mathrm{M}$ ), the DCF removal ratio increased from $68.93 \%$ to $97.27 \%$, and the $k$ value also increased, from 0.051 to $0.192 \mathrm{~min}^{-1}$. With the sustained increase of PM dosage (45-75 $\left.\mu \mathrm{M}\right)$, the DCF removal ratio and $k$ values decreased initially, then continued to increase. This unusual phenomenon (i.e., pollutant removal efficiency did not increase with the increasing of PM dosage) confused us. Therefore, the electrochemical characteristics of the MFC-PM process at different PM dosages were tested to explain this phenomenon. Interestingly, with the change of PM dosages, cathode potential and current density also changed. The trends of change in both of these were consistent with the trend of change in DCF removal 
efficiency (see Figure 2b). The results demonstrated that DCF removal efficiency was also related to the electrochemical nature. The higher power output of the MFC-PM process might be beneficial for activating PM and promoting the generation of reactive species, which could promote DCF removal. Additionally, Tafel plots were generated to evaluate electron transfer resistances via the exchange current densities and Tafel slopes, in which the exchange current densities expressed the rates of electron exchange at equilibrium, and Tafel slopes represented the electron transfer efficiencies [36,37]. As displayed in Figure 2c, the exchange current densities followed $60 \mu \mathrm{M}<15 \mu \mathrm{M} \approx 30 \mu \mathrm{M} \approx 45 \mu \mathrm{M}<75 \mu \mathrm{M}$, which represented that the rate of electron exchange containing $60 \mu \mathrm{M}$ PM concentration was the lowest. Moreover, the cathode of the MFC-PM process with $60 \mu \mathrm{M}$ PM concentration achieved the highest Tafel slope compared to the others, which indicated that the MFC-PM process at $60 \mu \mathrm{M}$ PM concentration possessed the lowest reaction activity. We speculated that the generated $\mathrm{MnO}_{\mathrm{x}}(\mathrm{x}=2$ or 1.5) might cover the active sites so that the active specific surface area of the electrode was reduced. Overall, there was no positive correlation between DCF removal efficiency and PM dosages in the MFC-PM process, and the $30 \mu \mathrm{M}$ $\mathrm{PM}$ dosage was the relatively optimal dosage, taking into account economic and manganese retention issues.
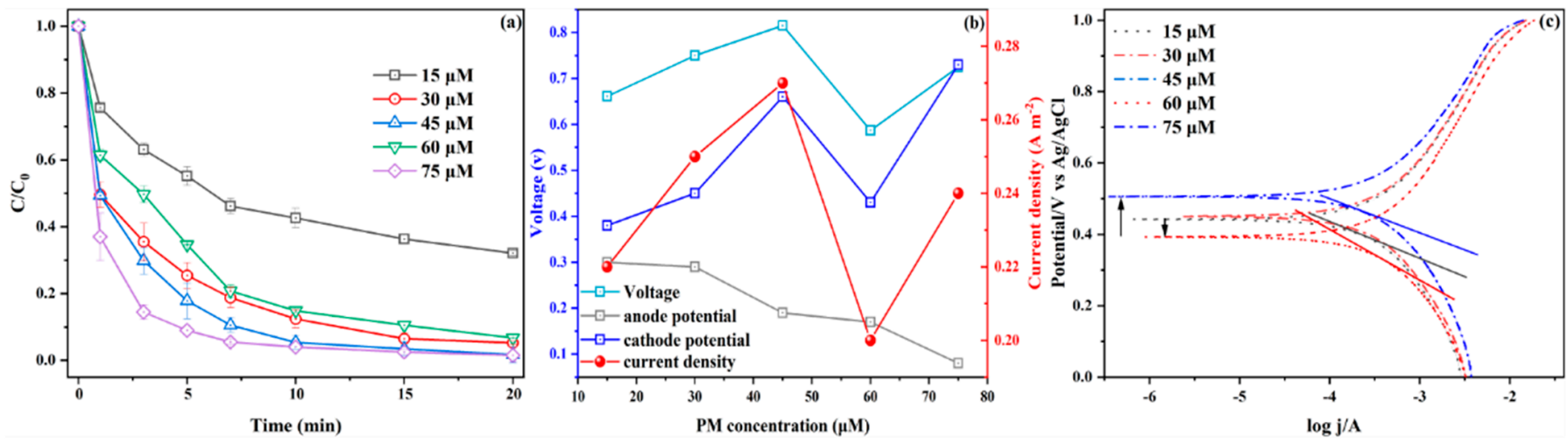

Figure 2. The DCF removal ratio (a), the change of voltage, cathode/anode potential, and current density (b), and Tafel curve $(\mathrm{c})$ in different PM concentrations $\left(\mathrm{pH}=3.0 ;[\mathrm{DCF}]_{0}=60 \mu \mathrm{M}\right.$; external resistances $=0 \Omega$ ).

\subsubsection{Effect of Catholyte $\mathrm{pH}$}

The influence of catholyte $\mathrm{pH}$ on DCF removal in the MFC-PM process was investigated. As displayed in Figure 3a,b, the removal efficiency of DCF and the consumption of PM were the highest under acidic conditions $(\mathrm{pH}=3.0)$. When the $\mathrm{pH}$ increased from 3.0 to 11.0, DCF removal efficiency and PM consumption both decreased significantly, which indicated that the MFC-PM process for DCF removal was a highly $\mathrm{pH}$-dependent reaction, and lower $\mathrm{pH}$ values were suitable for DCF removal. On one hand, the oxidation potential of $\mathrm{PM}$ decreased with increasing $\mathrm{pH}$, which could affect the reaction activity of PM (Equations (9)-(11)) [19]. On the other hand, the cathode potentials changed markedly, and arrived at the highest value in the condition of $\mathrm{pH}=3.0$. Additionally, the current density decreased from 24.5 to $14.8 \mathrm{~mA} \mathrm{~m}^{-2}$ as catholyte $\mathrm{pH}$ increased from 3.0 to 11.0. The decreasing cathodic potential and current density with increasing $\mathrm{pH}$ might also affect the removal of DCF (see Figure 3c). Furthermore, to further explore the phenomenon, we examined the electrochemical performance of the MFC-PM process at different $\mathrm{pH}$ values with the cyclic voltammetry $(\mathrm{CV})$ method. As displayed in Figure $3 \mathrm{~d}$, three reduction peaks $(-0.11 \mathrm{~V},-0.63 \mathrm{~V}$, and $-0.75 \mathrm{~V})$, and one oxidation peak $(-0.59 \mathrm{~V})$ at $\mathrm{pH}=3.0$ were observed and were different from the peaks observed at other $\mathrm{pH}$ values (5.0-11.0). Moreover, it was found that manganese intermediates could be formed under the potential of $-0.72 \mathrm{~V}$ (see Figure S1). The unique reduction peaks at $\mathrm{pH}=3.0$ indicated that manganese intermediates might only be formed at $\mathrm{pH}=3$ in the MFC-PM process [38]. Hence, combined with the reaction mechanism in Section 3.3.3, we speculated that the 
reduction peaks of $-0.11 \mathrm{~V},-0.63 \mathrm{~V}$, and $-0.75 \mathrm{~V}$ corresponded to the reaction processes of $\mathrm{Mn}(\mathrm{IV}) \rightarrow \mathrm{Mn}(\mathrm{III}), \mathrm{Mn}(\mathrm{VI}) \rightarrow \mathrm{Mn}(\mathrm{V}) / \mathrm{Mn}(\mathrm{IV})$, and $\mathrm{Mn}(\mathrm{VII}) \rightarrow \mathrm{Mn}(\mathrm{VI})$, respectively. The oxidation peak corresponded to the reaction processes of $\mathrm{Mn}(\mathrm{V}) \rightarrow \mathrm{Mn}(\mathrm{VI})$. Hence, $\mathrm{pH}=3.0$ was the optimal $\mathrm{pH}$ value in the MFC-PM process.

$$
\begin{array}{cc}
\text { Acidic condition: } \mathrm{MnO}_{4}{ }^{-}+5 \mathrm{e}^{-}+8 \mathrm{H}^{+} \rightarrow \mathrm{Mn}^{2+}+4 \mathrm{H}_{2} \mathrm{O} & \mathrm{E}^{0}=1.51 \mathrm{~V} \\
\text { Neutral condition: } \mathrm{MnO}_{4}{ }^{-}+3 \mathrm{e}^{-}+4 \mathrm{H}^{+} \rightarrow \mathrm{MnO}_{2}(\mathrm{~s})+2 \mathrm{H}_{2} \mathrm{O} & \mathrm{E}^{0}=1.70 \mathrm{~V} \\
\text { Alkaline condition: } \mathrm{MnO}_{4}{ }^{-}+3 \mathrm{e}^{-}+2 \mathrm{H}_{2} \mathrm{O} \rightarrow \mathrm{MnO}_{2}(\mathrm{~s})+4 \mathrm{OH}^{-} & \mathrm{E}^{0}=0.59 \mathrm{~V}
\end{array}
$$
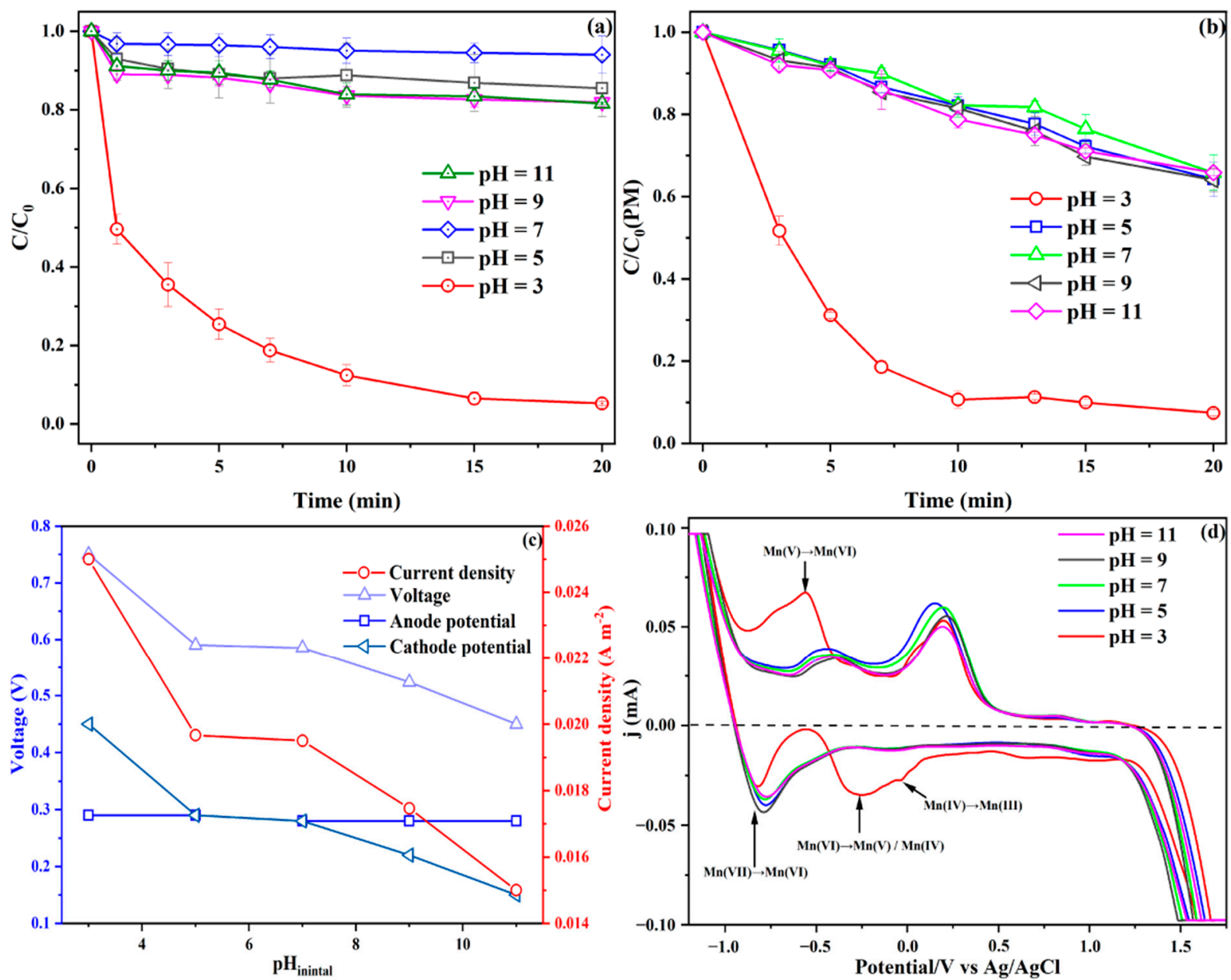

Figure 3. DCF removal (a), PM consumption (b), voltage, cathode/anode potential and current density (c), and cyclic voltammetry curve $(\mathbf{d})$ at different $\mathrm{pH}$ values $\left([\mathrm{PM}]_{0}=30 \mu \mathrm{M} ;[\mathrm{DCF}]_{0}=60 \mu \mathrm{M}\right.$; external resistance $\left.=0 \Omega\right)$.

\subsubsection{Effect of External Resistance}

To evaluate the influence of external resistance on DCF removal in the MFC-PM process, four different external resistances $(500,1000,2000$, and $5000 \Omega$ ) were examined. As displayed in Figure 4a and Table S4, although the external resistances had little influence on the DCF removal ratio, a significant influence was observed on the DCF removal rate. The removal rate decreased from 0.321 to $0.243 \mathrm{~min}^{-1}$ as the external resistance increased from 0 to $5000 \Omega$ within $3 \mathrm{~min}$. Moreover, the electrochemical performance at different external resistance values was also evaluated. As shown in Figure $4 \mathrm{~b}$, the output potential and current density all decreased with the increases in external resistance owing to the large diffusional resistance and overpotential $[39,40]$. Hence, the current density decreased from 0.41 to $0.07 \mathrm{~A} \mathrm{~m}^{-2}$ when the external resistance increased from 500 to $5000 \Omega$. This 
phenomenon might be due to the block of electron transport that inhibited the reaction in the cathode chamber. The potentials of the anode were $0.26(500 \Omega), 0.29(1000 \Omega)$, $0.32(2000 \Omega)$, and $0.35 \mathrm{~V}(5000 \Omega)$, respectively. As the external resistance increased, electrons migrated and accumulated in the anode, leading to the increase of potential in the anode [41]. Overall, reducing the external resistance was a beneficial approach for DCF removal.
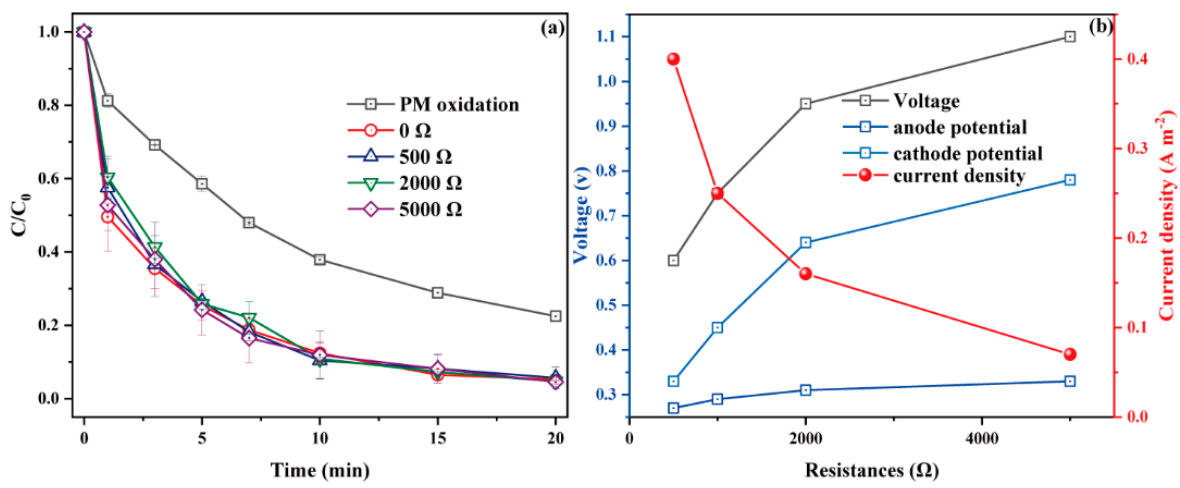

Figure 4. DCF removal (a), and voltage, cathode/anode potential and current density (b) at different values of external resistance $\left([\mathrm{PM}]_{0}=30 \mu \mathrm{M} ;[\mathrm{DCF}]_{0}=60 \mu \mathrm{M} ; \mathrm{pH}=3.0\right)$.

\subsection{Proposed Electron-Transfer and DCF Removal Mechanism}

\subsubsection{Identification of Reactive Species}

Conventional electrochemical oxidation systems could supply electrons directly from the power supply. In the MFC-PM process, electrons were generated from microorganisms by the metabolism of urea, and then transferred to the cathode via the external circuit. Our previous work proved that electrons on the surface of electrode (Pt) could activate PM to form $\mathrm{RMnS}$ and hydroxyl radical $\left(\mathrm{HO}^{\bullet}\right)$ for the removal of contaminants [24,25]. In the MFC-PM process, methyl alcohol (MA, broad spectrum quenching agent) and tert-butanol (TBA, $\mathrm{HO}^{\bullet}$ scavenger) were selected to detect the generation of $\mathrm{HO}^{\bullet}$ [42]. As shown in Figure S2a, with the increase of TBA and MA doses from $500 \mu \mathrm{M}$ to $100 \mathrm{mM}$, the DCF removal ratio was not significantly inhibited. That result indicated that $\mathrm{HO}^{\bullet}$ was not generated in the MFC-PM process or did not affect DCF removal [25]. Accordingly, manganese intermediates $\left(\mathrm{Mn}(\mathrm{VI})_{\mathrm{aq}}, \mathrm{Mn}(\mathrm{V})_{\mathrm{aq}}, \mathrm{Mn}(\mathrm{IV})_{\mathrm{s}}\right.$, and $\left.\mathrm{Mn}(\mathrm{III})_{\mathrm{aq}}\right)$ might be the reactive oxides in the MFC-PM process. Methyl phenyl sulfoxide (PMSO) was selected as a probe to ensure the presence of $\mathrm{Mn}(\mathrm{VI})_{\mathrm{aq}}$ and/or $\mathrm{Mn}(\mathrm{V})_{\mathrm{aq}}$ due to the specific products (e.g., methyl phenyl sulfone). Hence, methyl phenyl sulfone $\left(\mathrm{PMSO}_{2}\right)$ was the exclusive product of PMSO by $\mathrm{Mn}(\mathrm{VI})_{\mathrm{aq}}$ and/or $\mathrm{Mn}(\mathrm{V})_{\mathrm{aq}}$ oxidation, whereas hydroxylated and/or polymeric products would have been generated in the presence of $\mathrm{HO}^{\bullet}$. Furthermore, compared to other manganese intermediates, $\mathrm{PMSO}$ could be quickly oxidized into $\mathrm{PMSO}_{2}$ with stoichiometry 1:1 by $\mathrm{Mn}(\mathrm{VI})_{\mathrm{aq}}$ or $\mathrm{Mn}(\mathrm{V})_{\mathrm{aq}}$. Figure 5a shows that with the degradation of $\mathrm{PMSO}, \mathrm{PMSO}_{2}$ was gradually generated during the MFC-PM process. The ratio of $\triangle \mathrm{PMSO}_{2} / \triangle \mathrm{PMSO}$ was approaching $100 \%$, which indicated that $\mathrm{Mn}(\mathrm{VI})_{\mathrm{aq}}$ and / or $\mathrm{Mn}(\mathrm{V})_{\mathrm{aq}}$ were generated in the MFC-PM process. However, one question surrounded this process: was the transformation of manganese valence state via signal or double electron transfer modes? DFT calculation was utilized to elucidate the adsorption energy of different manganese intermediates on the surface of the $\mathrm{Pt}(111)$ lattice plane to further clarify the transformation mechanisms of manganese. As displayed in Figure 5b, all manganese intermediates adsorption energies on the $\mathrm{Pt}(111)$ lattice plane were negative values, which illustrated that manganese intermediates could be adsorbed and reacted in on the $\mathrm{Pt}(111)$ lattice plane. The adsorption energy of $\mathrm{Mn}(\mathrm{VI})(-1.52 \mathrm{eV})$ was lower than that of $\mathrm{Mn}(\mathrm{V})(-1.40 \mathrm{eV})$, indicating that $\mathrm{Mn}(\mathrm{VI})$ was easier to attach to the $\mathrm{Pt}(111)$ lattice plane. Hence, $\mathrm{PM}$ was more likely to be reduced via one electron mode on the $\mathrm{Pt}(111)$ lattice plane, resulting in the formation of more adsorptive $\mathrm{Mn}(\mathrm{VI})_{\mathrm{aq}}$. Besides, $\mathrm{Mn}(\mathrm{VI})_{\mathrm{aq}}$ and $\mathrm{Mn}(\mathrm{V})_{\mathrm{aq}}$ had characteristic absorption peaks 
at $610 \mathrm{~nm}$ and $660 \mathrm{~nm}$, respectively, which could have been further utilized to confirm the generation and change of $\mathrm{Mn}(\mathrm{VI})_{\mathrm{aq}}$ and $\mathrm{Mn}(\mathrm{V})_{\mathrm{aq}}$. Figure $5 \mathrm{c}$, d showed that with the increase of time, the absorbance of $\mathrm{Mn}(\mathrm{VI})_{\mathrm{aq}}$ and $\mathrm{Mn}(\mathrm{V})_{\mathrm{aq}}$ increased for a short time and gradually decreased. The largest peak of $\mathrm{Mn}(\mathrm{VI})_{\mathrm{aq}}$ appeared earlier than that of $\mathrm{Mn}(\mathrm{V})_{\mathrm{aq}}$, which indicated that $\mathrm{Mn}(\mathrm{VI})_{\mathrm{aq}}$ was formed first. In summary, these results above indicated that $\mathrm{PM}$ was preferred to reduce to $\mathrm{Mn}(\mathrm{VI})_{\mathrm{aq}}$ via one electron transfer first, and then $\mathrm{Mn}(\mathrm{VI})_{\mathrm{aq}}$ was further reduced to $\mathrm{Mn}(\mathrm{V})_{\mathrm{aq}}$.
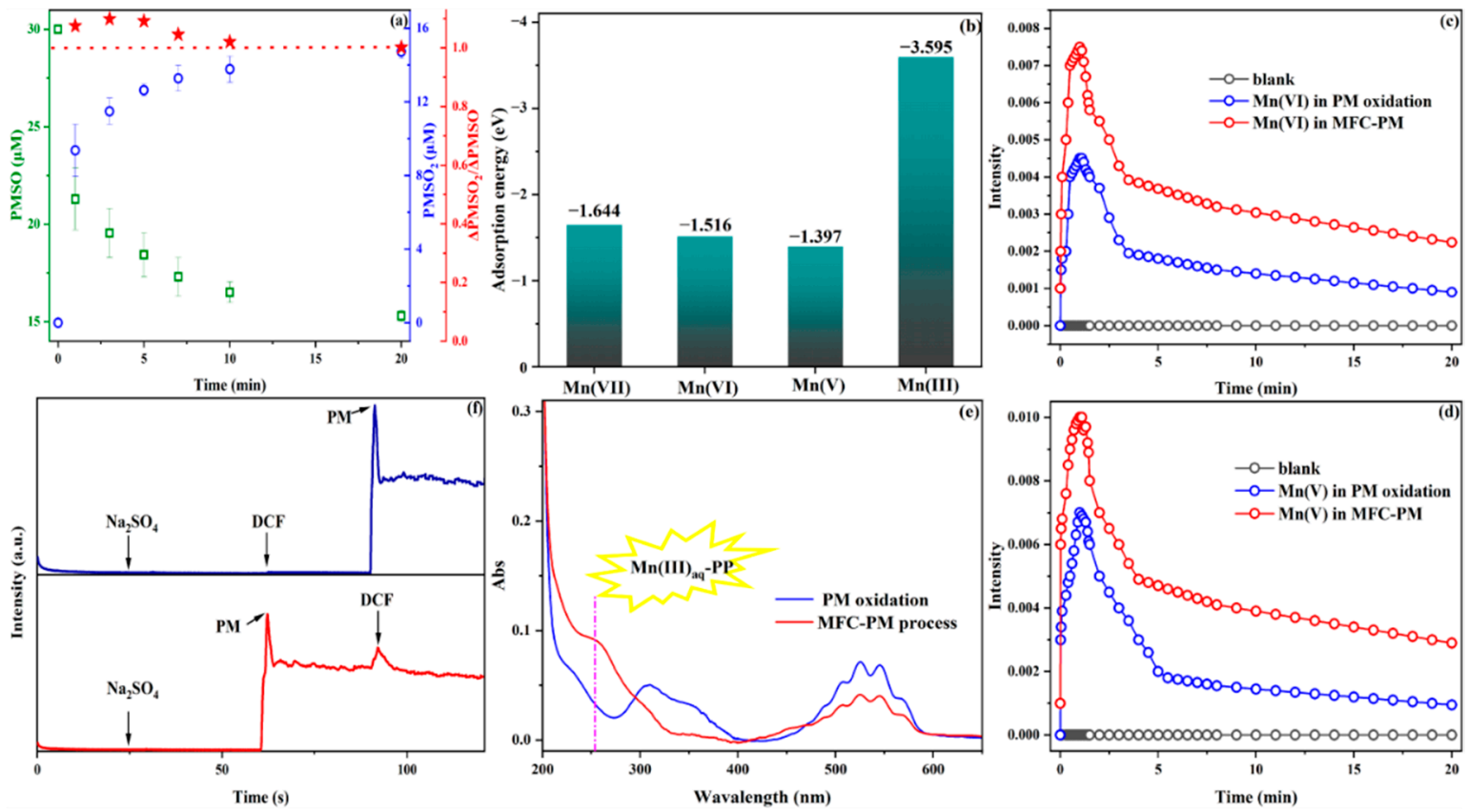

Figure 5. PMSO degradation and $\mathrm{PMSO}_{2}$ formation in the MFC-PM process (a), adsorption energies of different RMnS on $\mathrm{Pt}(111)$ lattice plane (b), $\mathrm{Mn}(\mathrm{V})_{\mathrm{aq}}(\mathbf{c})$ and $\mathrm{Mn}(\mathrm{VI})_{\mathrm{aq}}$ levels in the various processes (d), $\mathrm{UV}$-vis spectra of $\mathrm{Mn}(\mathrm{III})_{\mathrm{aq}}-\mathrm{PP}$ in the PM and MFC-PM processes after $20 \mathrm{~min}(\mathbf{e})$, and chronoamperometry in $0.05 \mathrm{M} \mathrm{Na}_{2} \mathrm{SO}_{4}$ electrolyte (f).

$\mathrm{Mn}(\mathrm{IV})_{\mathrm{s}}$ was a vital product produced in the PM catalytic oxidation process that could promote organic contaminant removal. The effect of $\mathrm{Mn}(\mathrm{IV})_{\mathrm{s}}$ in the MFC-PM process was studied. As displayed in Figure S2b, no apparent absorption peaks $(375-410 \mathrm{~nm})$ were observed. This result indicated that $\mathrm{Mn}(\mathrm{IV})_{\mathrm{s}}$ was absent in the MFC-PM process. Moreover, the effect of $\mathrm{Mn}(\mathrm{IV})_{\mathrm{s}}$ on DCF removal was also studied (see Figure S2c). The removal of DCF in the MFC- $\mathrm{MnO}_{2}$ process was restrained compared with that of the MFC-PM process. This result further demonstrated that $\mathrm{Mn}(\mathrm{IV})_{\mathrm{s}}$ had a slight effect on DCF removal.

$\mathrm{Mn}(\mathrm{III})$, a single-electron oxidant $\left(\mathrm{E}^{0}=1.51 \mathrm{~V}\right)$, might also contribute to DCF removal

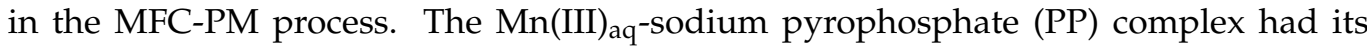
characteristic peak at $258 \mathrm{~nm}$, which could confirm the presence of $\mathrm{Mn}(\mathrm{III})_{\mathrm{aq}}$. As displayed in Figure S2d, with the addition of PP (from $500 \mu \mathrm{M}$ to $10 \mathrm{mM}$ ), DCF removal was inhibited significantly, which indicated that $\mathrm{Mn}(\mathrm{III})_{\text {aq }}$ played an important role in the MFC-PM process. In parallel, compared to the PM oxidation process, a complex peak of $\mathrm{Mn}(\mathrm{III})_{\mathrm{aq}}{ }^{-}$ PP was observed in the MFC-PM process (Figure 5e), which showed that Mn(III) aq was generated in the MFC-PM process. Moreover, with the increase of the PM/DCF ratio, the peak value of $\mathrm{Mn}(\mathrm{III})_{\mathrm{aq}}-\mathrm{PP}$ clearly increased (Figure S2e), indicating that $\mathrm{Mn}(\mathrm{III})_{\mathrm{aq}}$ contributed to the removal of DCF in the MFC-PM process. In addition, a novel MFC with multiple anodes and a single cathode (Figure S3) was also designed to gain more insight into the relationship between bio-electricity and the generation of $\mathrm{Mn}(\mathrm{III})_{\mathrm{aq}}$. Activated carbon fiber (ACF) was utilized as the cathode electrode in this novel system. The generation of $\mathrm{Mn}(\mathrm{III})_{\mathrm{aq}}$ was also detected. Interestingly, with the increase of the anode chamber, the peak 
of $\mathrm{Mn}(\mathrm{III})_{\mathrm{aq}}$-PP increased accordingly, illustrating that $\mathrm{Mn}(\mathrm{III})_{\mathrm{aq}}$ generation was directly related to the addition of bio-electricity.

Overall, RMnS (Mn(VI) $)_{\mathrm{aq}}, \mathrm{Mn}(\mathrm{V})_{\mathrm{aq}}$, and $\left.\mathrm{Mn}(\mathrm{III})_{\mathrm{aq}}\right)$ were formed and contributed to DCF removal in the MFC-PM process.

\subsubsection{Analysis of Electricity-Producing Communities}

Classifications of microbial communities were displayed in Figure S4. Four taxa were evaluated at the phylum level, comprising Firmicutes (42.5\%), Actinobacteria (23.7\%), Proteobacteria $(19.1 \%)$, and Bacteroidetes $(12.0 \%)$, respectively. Firmicutes and Proteobacteria were typical anaerobic electroactive bacteria that could transfer electrons via nanowires, electrokinesis, and outer-membrane cytochromes [34,43]. Moreover, Bacteroidetes, ranking third in total number, could also export electrons to the Pt electrode [44]. In contrast, Actinobacteria, ranking second in total number, had no electrochemical activity. The presence of Actinobacteria in the cathode chamber might be because it is commonly in inoculated sludge and continued to reproduce on urea nutrient sources [45]. Additionally, further analysis at the genus level indicated that Pseudogracilibacillus was dominant on the carbon brush electrodes $(12.8 \%)$.

\subsubsection{Reaction Mechanism}

In addition to the evidence mentioned above, chronoamperometry was also utilized to ascertain the reaction dynamics of the MFC-PM process (Figure 5f). The addition of $50 \mathrm{mM} \mathrm{Na}_{2} \mathrm{SO}_{4}$ had no effect on the response current, which indicated that the increase of electrolyte ions in the solution had no effect on electron transfer. However, with the addition of PM at $60 \mathrm{~s}$, the current increased significantly, indicating PM was reduced on the Pt electrode. An obvious current response was observed with the addition of DCF at $120 \mathrm{~s}$, indicating that electron transfer between the DCF and the reacting electrode had occurred. Moreover, when DCF was added to the solution at $60 \mathrm{~s}$, no obvious response current was observed. This result indicated that there was no direct electron transfer between DCF and origin Pt electrodes. Overall, the evidence indicated that PM was first reduced to RMnS via combination with electrons, which were generated by Firmicutes bacteria. The RMnS could transform into each other and oxidize DCF (Equations (12)-(19)) [17,24,25]. A simplified reaction pathway for DCF removal in the MFC-PM process was proposed and is illustrated in graphic abstract.

$$
\begin{gathered}
\mathrm{Mn}(\mathrm{VII})_{\mathrm{aq}}+\mathrm{e}^{-} \rightarrow \mathrm{Mn}(\mathrm{VI})_{\mathrm{aq}} \\
\mathrm{Mn}(\mathrm{VI})_{\mathrm{aq}}+\mathrm{e}^{-} \rightarrow \mathrm{Mn}(\mathrm{V})_{\mathrm{aq}} \\
\mathrm{Mn}(\mathrm{V})_{\mathrm{aq}}+2 \mathrm{e}^{-} \rightarrow \mathrm{Mn}(\mathrm{III})_{\mathrm{aq}} \\
\mathrm{Mn}(\mathrm{V})_{\mathrm{aq}}+\mathrm{e}^{-} \rightarrow \mathrm{Mn}(\mathrm{IV})_{\mathrm{s}} \\
2 \mathrm{Mn}(\mathrm{V})_{\mathrm{aq}} \rightarrow \mathrm{Mn}(\mathrm{VI})_{\mathrm{aq}}+\mathrm{Mn}(\mathrm{IV})_{\mathrm{s}} \\
\mathrm{Mn}(\mathrm{III})_{\mathrm{aq}}+\mathrm{e}^{-} \rightarrow \mathrm{Mn}(\mathrm{II}) \\
2 \mathrm{MnO}_{4}{ }^{-}+3 \mathrm{Mn}^{2+}+16 \mathrm{H}^{+}+5 \mathrm{e}^{-} \rightarrow 5 \mathrm{Mn}(\mathrm{III})_{\mathrm{aq}}+8 \mathrm{H}_{2} \mathrm{O} \\
\mathrm{RMnS}^{2} \text { pollutant } \rightarrow \text { products }
\end{gathered}
$$

\subsubsection{Degradation Pathways of DCF}

HPLC/MS analysis and DFT calculation were employed to elucidate the degradation pathway of DCF in the MFC-PM process. At first, the Fukui index, representing electrophilic attack $(f-)$ and the natural population analysis charge distribution were calculated to predict the location of DCF that RMnS might attack. As displayed in Figure 6a,b, C2, $\mathrm{C} 7, \mathrm{C} 12, \mathrm{C} 13$, and $\mathrm{C} 17$ possessed relative larger $f$-values, which meant that these locations were more vulnerable to RMnS attack in theory [46]. Furthermore, combined with the HPLC/MS results and DFT calculation, a possible degradation pathway was proposed. As shown in Figure 6c, first, DCF degradation was classified into three routes: ring opening, 
ring hydroxylation, and decarboxylation. In the ring opening pathway, the $\mathrm{C} 2$ atom was attacked, leading to the generation of P8 $(\mathrm{m} / \mathrm{z} 346)$, and then P8 $(\mathrm{m} / \mathrm{z} 346)$ was converted to $\mathrm{P} 10(\mathrm{~m} / \mathrm{z} 318)$ by hydrolysis and ring closure. In the ring hydroxylation pathway, the $\mathrm{C} 7$ atom with the highest $f$ - (0.1962) was attacked to form P1 $(\mathrm{m} / z 312)$ and P4 $(\mathrm{m} / z 267)$, and $\mathrm{P} 1$ and $\mathrm{P} 4$ were converted to $\mathrm{P} 3(\mathrm{~m} / \mathrm{z} 283)$ and $\mathrm{P} 5(\mathrm{~m} / \mathrm{z} 266)$, respectively, by a multi-step decarboxylation and oxidation; DCF underwent decarboxylation and C-N cleavage to eventually form P7 ( $m / z$ 161). Finally, the intermediates could be further attacked by reactive species to cleave into smaller molecules (e.g., $\mathrm{CO}_{2}$ and $\mathrm{H}_{2} \mathrm{O}$ ).

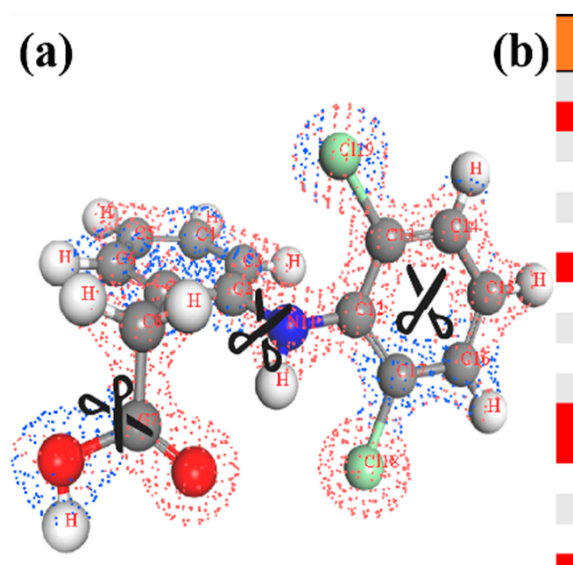

(c)

(b)

\begin{tabular}{|c|c|c|c|c|c|c|}
\hline Atom & $\begin{array}{l}\text { Charge } \\
\text { (I) }\end{array}$ & $\begin{array}{c}\text { Charge } \\
(+)\end{array}$ & $\begin{array}{c}\text { Charge } \\
(-)\end{array}$ & $f^{0}$ & $f^{+}$ & $f$ \\
\hline C1 & 0.031 & 0.023 & 0.04 & -0.0084 & -0.0044 & -0.0107 \\
\hline C 2 & 0.024 & 0.02 & 0.029 & 0.0376 & 0.0406 & 0.0357 \\
\hline $\mathrm{C} 3$ & 0.03 & 0.017 & 0.044 & -0.0611 & -0.0568 & -0.0628 \\
\hline $\mathrm{C}_{4}$ & 0.042 & 0.045 & 0.039 & -0.0433 & -0.0394 & -0.0478 \\
\hline C5 & 0.061 & 0.043 & 0.078 & -0.0561 & -0.0483 & -0.0605 \\
\hline $\mathrm{C} 6$ & 0.031 & 0.025 & 0.038 & -0.0494 & -0.0455 & -0.0518 \\
\hline C 7 & 0.042 & 0.076 & 0.008 & 0.1954 & 0.1962 & 0.1877 \\
\hline C 8 & 0.015 & 0.02 & 0.01 & -0.0558 & -0.0548 & -0.0578 \\
\hline 09 & 0.04 & 0.069 & 0.011 & -0.2432 & -0.2423 & -0.2504 \\
\hline 010 & 0.039 & 0.056 & 0.023 & -0.1541 & -0.1518 & -0.1597 \\
\hline N 11 & 0.056 & 0.009 & 0.103 & -0.1074 & -0.0972 & -0.1084 \\
\hline $\mathrm{C} 12$ & 0.025 & 0.038 & 0.013 & 0.0306 & 0.0319 & 0.0268 \\
\hline $\mathrm{C} 13$ & 0.022 & 0.02 & 0.024 & 0.0131 & 0.0156 & 0.0113 \\
\hline $\mathrm{C} 14$ & 0.036 & 0.043 & 0.03 & -0.055 & -0.0519 & -0.0592 \\
\hline C 15 & 0.064 & 0.068 & 0.059 & -0.0458 & -0.0397 & -0.0524 \\
\hline C 16 & 0.032 & 0.032 & 0.032 & -0.0549 & -0.0517 & -0.0581 \\
\hline C17 & 0.03 & 0.032 & 0.029 & 0.0096 & 0.0125 & 0.0065 \\
\hline Cl 18 & 0.064 & 0.058 & 0.07 & -0.0108 & -0.0039 & -0.0166 \\
\hline
\end{tabular}

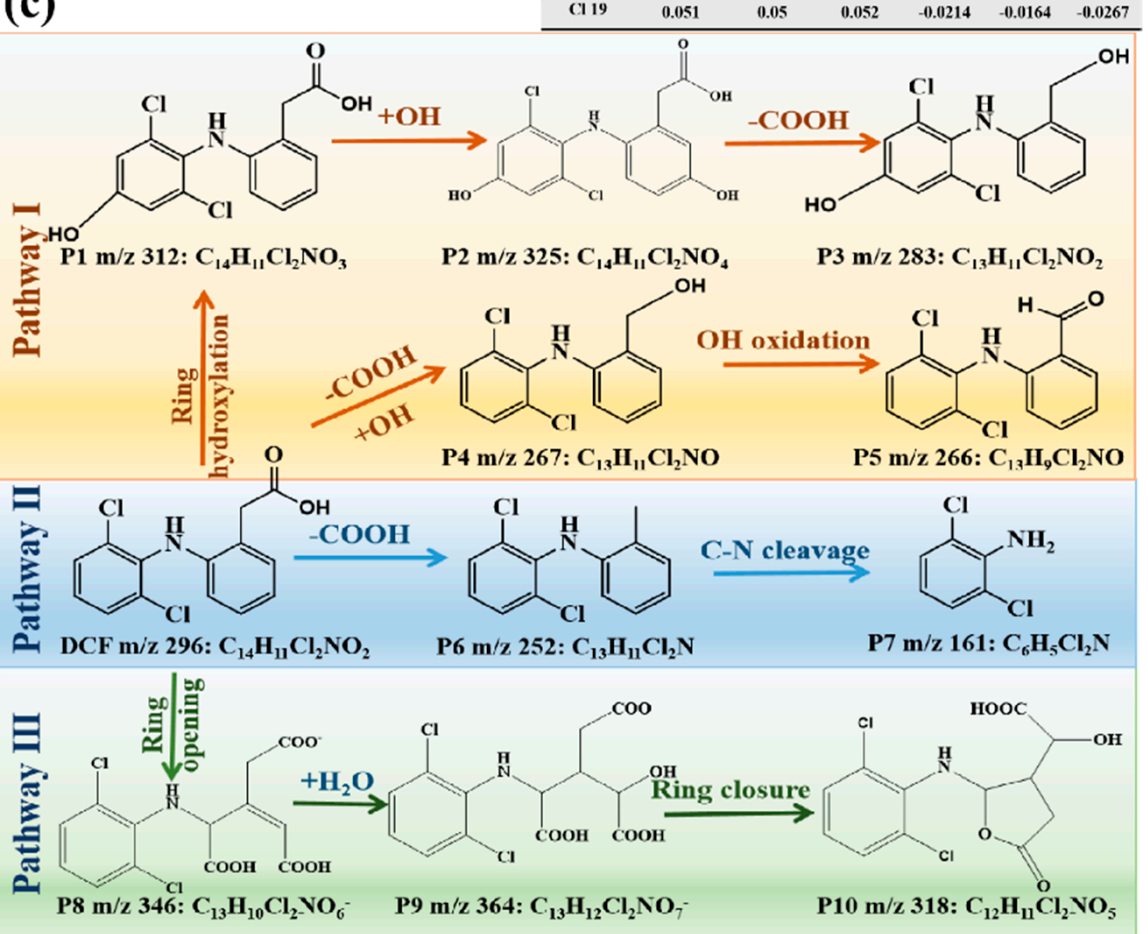

Figure 6. DCF electronic cloud density (a), NPA charge distribution and Fukui index of DCF (b), and degradation pathway of DCF (c).

\subsection{Application of the MFC-PM Process}

As displayed in Figure S5a, different water matrices (surface and tap water) were utilized to determine the practicability of the MFC-PM process for DCF removal. The characteristics of water matrices utilized in this study were investigated. It may be seen that the removal of DCF in the tap and surface water reached $95.32 \%$ and $82.05 \%$, respectively, which were slightly reduced compared with that of ultrapure water. The $k$ values were 0.106 
and $0.083 \mathrm{~min}^{-1}$ in tap water and surface water, respectively (Table S4). This result was consistent with previous reports that the non-radical oxidation process was less affected by the water matrices in comparison to the radical oxidation process [27]. The result also indicated that DCF could be effectively removed in the MFC-PM process in natural water. However, the DCF removal rate in ultrapure water was faster than that of tap or surface water. This phenomenon might be attributed to background organic matter and inorganic salts in the surface water and tap water, such as $\mathrm{NO}_{3}{ }^{-}, \mathrm{H}_{2} \mathrm{PO}_{4}{ }^{-}$, and $\mathrm{HCO}_{3}{ }^{-}$, which affected the performance of the PM oxidation system. Moreover, Jia et al., proved that inorganic salts may competitively react with electrons produced from MFC [47]. Hence, the effect of anions on the MFC-PM process was studied. As shown in Figure $\mathrm{S} 5 \mathrm{~b}-\mathrm{f}, \mathrm{HCO}_{3}{ }^{-}$, lower concentrations of $\mathrm{Cl}^{-}, \mathrm{HPO}_{4}{ }^{-}, \mathrm{NO}_{3}{ }^{-}$, and lower concentrations of humic acid (HA) all inhibited the removal of DCF, whereas higher concentrations of $\mathrm{HA}$ and $\mathrm{Cl}^{-}$enhanced the reaction. $\mathrm{HCO}_{3}{ }^{-}$and $\mathrm{HPO}_{4}{ }^{-}$were frequently considered to have a negative effect on pollutant degradation in the PM catalytic oxidation process by competing for catalytic sites and influencing the solution $\mathrm{pH}$. Hence, we speculated that $\mathrm{pH}$ values during reaction could be altered by $\mathrm{HCO}_{3}{ }^{-}$and $\mathrm{HPO}_{4}{ }^{-}$, which could account for the inhibitory effect. The $\mathrm{pH}$ during the MFC-PM process in the presence of $\mathrm{HCO}_{3}{ }^{-}$and $\mathrm{HPO}_{4}{ }^{-}$was examined to test that speculation. With the presence of $\mathrm{HCO}_{3}{ }^{-}$and $\mathrm{HPO}_{4}{ }^{-}$, the $\mathrm{pH}$ was at 7.0 and 6.5 , respectively. These values were higher than that of the blank process (i.e., MFC-PM process) $(\mathrm{pH}=3.2)$, in which a higher $\mathrm{pH}$ value was not favorable for DCF removal. While $\mathrm{NO}_{3}-$ could not adjust solution $\mathrm{pH}$, the inhibitory effect caused by $\mathrm{NO}_{3}{ }^{-}$might be due to the competition of $\mathrm{NO}_{3}{ }^{-}$(Equations (20) and (21)) with PM for electrons on the cathode, which resulted in the reduction of intermediate manganese generation [47]. As for HA and $\mathrm{Cl}^{-}$, at low concentrations, they might compete with electrons in cathodes, resulting in the reduced generation of RMnS, whereas at higher concentrations they might react with $\mathrm{RMnS}$ to generate other reactive species (e.g., ${ }^{\bullet} \mathrm{OH}, \mathrm{Cl}^{\bullet}$, etc.) to accelerate the MFC-PM process $[24,48]$. Additionally, the removal rate of DCF in urea solution was also evaluated to further assess the applicability of the MFC-PM process. As shown in Figure S6, with the increase in urea concentration, DCF removal efficiency was significantly promoted, indicating that the MFC-PM process was an effective method in removing DCF in urine.

$$
\begin{gathered}
\mathrm{NO}_{3}{ }^{-}+2 \mathrm{e}^{-}+2 \mathrm{H}^{+} \rightarrow \mathrm{NO}_{2}{ }^{-}+\mathrm{H}_{2} \mathrm{O} \\
\mathrm{NO}_{2}{ }^{-}+3 \mathrm{e}^{-}+3 \mathrm{H}^{+} \rightarrow \mathrm{OH}^{-}+\mathrm{H}_{2} \mathrm{O}+0.5 \mathrm{~N}_{2}
\end{gathered}
$$

\section{Conclusions}

A novel MFC-PM process was successfully developed for DCF removal in a cathode chamber. Free RMnS were the main oxides and were generated by combination with electrons from Firmicutes, Actinobacteria, Proteobacteria, and Bacteroidetes. Ring opening, ring hydroxylation, and decarboxylation were the main degradation pathways. Common anions in natural water had negligible effect on the removal of DCF, whereas higher concentrations of $\mathrm{HA}$ and $\mathrm{Cl}^{-}$promoted DCF removal. Moreover, DCF could be effectively removed in actual water and urea water. This paper provided a novel energy-free method of activating PM for DCF removal via generated RMnS in situ.

Supplementary Materials: The following are available online at https: / www.mdpi.com/article / 10.3390/w13152047/s1, Figure S1: The change of voltage with time (a), cyclic voltammetry curve of PM (b), and UV-vis spectrum of PM under different potentials (c), Figure S2: Effect of MA, TBA (a), UV-vis spectra of the the MFC-PM processes (b), effect of $\mathrm{MnO}_{2}$ (c) and PP (d) on the removal of $\mathrm{DCF}$, and the peaks of $\mathrm{Mn}(\mathrm{III})_{\mathrm{aq}}(\mathrm{e})$ in different PM/DCF ratios with $10 \mathrm{mM}$ PP, Figure S3: Diagram of MFC with muti-anodes and single cathode and UV-vis spectra with one anode (a), two anodes (b), three anodes (c) in the MFC-PM system, and comparison with peaks of Mn(III) aq with different numbers of anodes (d), Figure S4: Taxonomy of microbial communities classified at the phylum level on the anode of MFC, Figure S5: Effect of water matrices (a), $\mathrm{HPO}_{4}{ }^{2-}$ (b), $\mathrm{NO}_{3}{ }^{-}$(c), $\mathrm{Cl}^{-}$(d), $\mathrm{HCO}_{3}{ }^{-}(\mathrm{e})$, and HA (f) on the removal of DCF in the MFC-PM system, Figure S6: Effect of urea 
on the removal of DCF in the MFC-PM system, Table S1: Elemental composition of minerals, Table S2: Composition of vitamin solutions, Table S3: Comparison of the MFC-PM process with other methods for the degradation of DCF, Table S4: The reaction kinetics of DCF removal in different PM concentrations, external resistances, and water matrices by the MFC-PM process.

Author Contributions: X.W.: investigation, methodology, validation, formal analysis, writingoriginal draft; Y.W. and J.Z.: methodology, validation; P.D.: DFT calculation; L.Z.: validation; S.U.H.: investigation and writing, editing; A.B. and I.W.: conceptualization, writing-review and editing and funding acquisition; C.Z.: supervision and writing-review and editing. All authors have read and agreed to the published version of the manuscript.

Funding: This research was funded by "The Program of the National Science Foundation, grant number 22076015"; “The Chongqing Natural Science Foundation Project, grant number cstc2019jcyjmsxmX0463"; "Graduate Scientific Research and Innovation Foundation of Chongqing, grant number CYB19030"; and "the 111 Proiect, grant number B13041".

Acknowledgments: We thank Analytical and Testing Center of Chongqing University for analysis.

Conflicts of Interest: The authors declare no conflict of interest.

\section{References}

1. Plakas, K.V.; Mantza, A.; Sklari, S.D.; Zaspalis, V.T.; Karabelas, A.J. Heterogeneous Fenton-like oxidation of pharmaceutical diclofenac by a catalytic iron-oxide ceramic microfiltration membrane. Chem. Eng. J. 2019, 373, 700-708. [CrossRef]

2. De Oliveira, T.; Guegan, R.; Thiebault, T.; Le Milbeau, C.; Muller, F.; Teixeira, V.; Giovanela, M.; Boussafir, M. Adsorption of diclofenac onto organoclays: Effects of surfactant and environmental ( $\mathrm{pH}$ and temperature) conditions. J. Hazard. Mater. 2017, 323, 558-566. [CrossRef]

3. Vieno, N.; Sillanpaa, M. Fate of diclofenac in municipal wastewater treatment plant-A review. Environ. Int. 2014, 69, 28-39. [CrossRef] [PubMed]

4. Khan, S.J.; Ongerth, J.E. Modelling of pharmaceutical residues in Australian sewage by quantities of use and fugacity calculations. Chemosphere 2004, 54, 355-367. [CrossRef] [PubMed]

5. Clara, M.; Strenn, B.; Gans, O.; Martinez, E.; Kreuzinger, N.; Kroiss, H. Removal of selected pharmaceuticals, fragrances and endocrine disrupting compounds in a membrane bioreactor and conventional wastewater treatment plants. Water Res. 2005, 39, 4797-4807. [CrossRef]

6. Davies, N.M.; Anderson, K.E. Clinical pharmacokinetics of diclofenac-Therapeutic insights and pitfalls. Clin. Pharmacokinet. 1997, 33, 184-213. [CrossRef] [PubMed]

7. Stierlin, H.; Faigle, J.W.; Sallmann, A.; Kung, W.; Richter, W.J.; Kriemler, H.P.; Alt, K.O.; Winkler, T. Biotransformation of Diclofenac Sodium (Voltaren) in Animals and in Man: 1. Isolation and Identification of Principal Metabolites. Xenobiotica 1979, 9, 601-610. [CrossRef] [PubMed]

8. Zhao, Z.; Zhang, W.; Liu, W.; Li, Y.; Ye, J.; Liang, J.; Tong, M. Activation of sulfite by single-atom Fe deposited graphitic carbon nitride for diclofenac removal: The synergetic effect of transition metal and photocatalysis. Chem. Eng. J. 2021, 407, 127167. [CrossRef]

9. Bae, S.; Kim, D.; Lee, W. Degradation of diclofenac by pyrite catalyzed Fenton oxidation. Appl. Catal. B Environ. 2013, 134, 93-102. [CrossRef]

10. Dobrin, D.; Bradu, C.; Magureanu, M.; Mandache, N.B.; Parvulescu, V.I. Degradation of diclofenac in water using a pulsed corona discharge. Chem. Eng. J. 2013, 234, 389-396. [CrossRef]

11. Perisic, D.J.; Gilja, V.; Stankov, M.N.; Katancic, Z.; Kusic, H.; Stangar, U.L.; Dionysiou, D.D.; Bozic, A.L. Removal of diclofenac from water by zeolite-assisted advanced oxidation processes. J. Photochem. Photobiol. A Chem. 2016, 321, 238-247. [CrossRef]

12. Plakas, K.V.; Sklari, S.D.; Yiankakis, D.A.; Sideropoulos, G.T.; Zaspalis, V.T.; Karabelas, A.J. Removal of organic micropollutants from drinking water by a novel electro-Fenton filter: Pilot-scale studies. Water Res. 2016, 91, 183-194. [CrossRef] [PubMed]

13. Naddeo, V.; Belgiorno, V.; Ricco, D.; Kassinos, D. Degradation of diclofenac during sonolysis, ozonation and their simultaneous application. Ultrason. Sonochem. 2009, 16, 790-794. [CrossRef]

14. Cheng, H.; Song, D.; Liu, H.; Qu, J. Permanganate oxidation of diclofenac: The $\mathrm{pH}$-dependent reaction kinetics and a ring-opening mechanism. Chemosphere 2015, 136, 297-304. [CrossRef] [PubMed]

15. Lu, X.; Shao, Y.; Gao, N.; Chen, J.; Zhang, Y.; Xiang, H.; Guo, Y. Degradation of diclofenac by UV-activated persulfate process: Kinetic studies, degradation pathways and toxicity assessments. Ecotoxicol. Environ. Saf. 2017, 141, 139-147. [CrossRef] [PubMed]

16. Peng, J.; Zhou, P.; Zhou, H.; Liu, W.; Zhang, H.; Zhou, C.; Lai, L.; Ao, Z.; Su, S.; Lai, B. Insights into the Electron-Transfer Mechanism of Permanganate Activation by Graphite for Enhanced Oxidation of Sulfamethoxazole. Environ. Sci. Technol. 2021. [CrossRef] [PubMed]

17. Song, Y.; Zhao, C.; Wang, T.; Kong, Z.; Zheng, L.; Ding, H.; Liu, Y.; Zheng, H. Simultaneously promoted reactive manganese species and hydroxyl radical generation by electro-permanganate with low additive ozone. Water Res. 2020, 189, 116623. [CrossRef] [PubMed] 
18. Gao, Y.; Zhou, Y.; Pang, S.; Jiang, J.; Yang, Z.; Shen, Y.; Wang, Z.; Wang, P.; Wang, L. New Insights into the Combination of Permanganate and Bisulfite as a Novel Advanced Oxidation Process: Importance of High Valent Manganese-Oxo Species and Sulfate Radical. Environ. Sci. Technol. 2019, 53, 3689-3696. [CrossRef]

19. Chen, J.; Rao, D.; Dong, H.; Sun, B.; Shao, B.; Cao, G.; Guan, X. The role of active manganese species and free radicals in permanganate/bisulfite process. J. Hazard. Mater. 2020, 388, 121735. [CrossRef]

20. Tian, S.; Wang, L.; Liu, Y.; Yang, T.; Huang, Z.; Wang, X.; He, H.; Jiang, J.; Ma, J. Enhanced Permanganate Oxidation of Sulfamethoxazole and Removal of Dissolved Organics with Biochar: Formation of Highly Oxidative Manganese Intermediate Species and in Situ Activation of Biochar. Environ. Sci. Technol. 2019, 53, 5282-5291. [CrossRef]

21. Shi, Z.; Jin, C.; Zhang, J.; Zhu, L. Insight into mechanism of arsanilic acid degradation in permanganate-sulfite system: Role of reactive species. Chem. Eng. J. 2019, 359, 1463-1471. [CrossRef]

22. Sun, B.; Li, D.; Linghu, W.; Guan, X. Degradation of ciprofloxacin by manganese(III) intermediate: Insight into the potential application of permanganate/bisulfite process. Chem. Eng. J. 2018, 339, 144-152. [CrossRef]

23. Guo, K.; Zhang, J.; Li, A.; Xie, R.; Liang, Z.; Wang, A.; Ling, L.; Li, X.; Li, C.; Fang, J. Ultraviolet Irradiation of Permanganate Enhanced the Oxidation of Micropollutants by Producing HO• and Reactive Manganese Species. Environ. Sci. Technol. Lett. 2018, 5, 750-756. [CrossRef]

24. Zhu, Y.; Wang, X.; Zhang, J.; Ding, L.; Li, J.; Zheng, H.; Zhao, C. Generation of Active Mn(III)aq by a Novel Heterogeneous Electro-permanganate Process with Manganese(II) as Promoter and Stabilizer. Environ. Sci. Technol. 2019, 53, 9063-9072. [CrossRef]

25. Zhu, Y.; Zhao, C.; Liang, J.; Shang, R.; Zhu, X.; Ding, L.; Deng, H.; Zheng, H.; Strathmann, T.J. Rapid removal of diclofenac in aqueous solution by soluble $\mathrm{Mn}(\mathrm{III})$ (aq) generated in a novel Electro-activated carbon fiber-permanganate (E-ACF-PM) process. Water Res. 2019, 165, 114975. [CrossRef] [PubMed]

26. Gude, V.G. Wastewater treatment in microbial fuel cells-an overview. J. Clean. Prod. 2016, 122, 287-307. [CrossRef]

27. Zhang, J.; Wang, Z.; Chu, L.; Chen, R.; Zhang, C.; Toan, S.; Bagley, D.M.; Sun, J.; Dong, S.; Fan, M. Unified photoelectrocatalytic microbial fuel cell harnessing $3 \mathrm{D}$ binder-free photocathode for simultaneous power generation and dual pollutant removal. $J$. Power Sources 2021, 481, 229133. [CrossRef]

28. Ahmadpour, T.; Aber, S.; Hosseini, M.G. Improved dye degradation and simultaneous electricity generation in a photoelectrocatalytic microbial fuel cell equipped with $\mathrm{AgBr} / \mathrm{CuO}$ hybrid photocathode. J. Power Sources 2020, 474, 228589. [CrossRef]

29. Xu, P.; Zheng, D.; He, Q.; Yu, J. The feasibility of ofloxacin degradation and electricity generation in photo-assisted microbial fuel cells with LiNbO3/CF photocatalytic cathode. Sep. Purif. Technol. 2020, 250, 117106. [CrossRef]

30. Yu, X.; Fu, W.; Jiang, M.; Liu, G.; Zou, Y.; Chen, S. Automatic microbial electro-Fenton system driven by transpiration for degradation of acid orange 7. Sci. Total Environ. 2020, 725, 138508. [CrossRef]

31. Zou, R.; Angelidaki, I.; Yang, X.; Tang, K.; Andersen, H.R.; Zhang, Y. Degradation of pharmaceuticals from wastewater in a 20-L continuous flow bio-electro-Fenton (BEF) system. Sci. Total Environ. 2020, 727, 138684. [CrossRef]

32. Zhao, H.; Zhang, Q. Performance of electro-Fenton process coupling with microbial fuel cell for simultaneous removal of herbicide mesotrione. Bioresour. Technol. 2021, 319, 124244. [CrossRef]

33. Yan, S.; Zhang, X.; Shi, Y.; Zhang, H. Natural Fe-bearing manganese ore facilitating bioelectro-activation of peroxymonosulfate for bisphenol A oxidation. Chem. Eng. J. 2018, 354, 1120-1131. [CrossRef]

34. Long, X.; Wang, H.; Wang, C.; Cao, X.; Li, X. Enhancement of azo dye degradation and power generation in a photoelectrocatalytic microbial fuel cell by simple cathodic reduction on titania nanotube arrays electrode. J. Power Sources 2019, 415, 145-153. [CrossRef]

35. Kageshima, Y.; Yoshimura, T.; Koh, S.; Mizuno, M.; Teshima, K.; Nishikiori, H. Photoelectrochemical Complete Decomposition of Cellulose for Electric Power Generation. Chemcatchem 2021, 13, 1530-1537. [CrossRef]

36. Theerthagiri, J.; Lee, S.J.; Murthy, A.P.; Madhavan, J.; Choi, M.Y. Fundamental aspects and recent advances in transition metal nitrides as electrocatalysts for hydrogen evolution reaction: A review. Curr. Opin. Solid State Mater. Sci. 2020, $24,100805$. [CrossRef]

37. Lee, S.J.; Theerthagiri, J.; Choi, M.Y. Time-resolved dynamics of laser-induced cavitation bubbles during production of Ni nanoparticles via pulsed laser ablation in different solvents and their electrocatalytic activity for determination of toxic nitroaromatics. Chem. Eng. J. 2021, 427, 130970. [CrossRef]

38. Wen, Q.; Yang, T.; Wang, S.; Chen, Y.; Cong, L.; Qu, Y. Dechlorination of 4-chlorophenol to phenol in bioelectrochemical systems. J. Hazard. Mater. 2013, 244, 743-749. [CrossRef] [PubMed]

39. Chandraserkharan Meenu, P.; Sreelekshmy, B.R.; Basheer, R.; Sadasivan, S.M.; Vijayakumari Ramakrishnan, R.M.; Shibli, S.M.A. Development of a High-Performance Mediatorless Microbial Fuel Cell Comprising a Catalytic Steel Anode. ACS Appl. Bio Mater. 2018, 1, 1124-1133. [CrossRef]

40. Kusmierek, E. Semiconductor Electrode Materials Applied in Photoelectrocatalytic Wastewater Treatment-an Overview. Catalysts 2020, 10, 439. [CrossRef]

41. Li, M.; Zhou, S. Efficacy of $\mathrm{Cu}(\mathrm{II})$ as an electron-shuttle mediator for improved bioelectricity generation and $\mathrm{Cr}(\mathrm{VI}) \mathrm{reduction}$ in microbial fuel cells. Bioresour. Technol. 2019, 273, 122-129. [CrossRef] [PubMed] 
42. Wang, X.; Hu, X.; Zhao, C.; Sun, Z.; Zheng, H.; Li, J.; Wang, Z. Optimization and mechanism of Acid Orange 7 removal by powdered activated carbon coupled with persulfate by response surface method. Water Sci. Technol. 2019, 79, 1195-1205. [CrossRef] [PubMed]

43. Zhang, K.; Wu, X.; Luo, H.; Li, X.; Chen, W.; Chen, J.; Mo, Y.; Wang, W. $\mathrm{CH}_{4}$ control and associated microbial process from constructed wetland (CW) by microbial fuel cells (MFC). J. Environ. Manag. 2020, 260, 110071. [CrossRef] [PubMed]

44. Zhao, H.; Kong, C. Enhanced removal of p-nitrophenol in a microbial fuel cell after long-term operation and the catabolic versatility of its microbial community. Chem. Eng. J. 2018, 339, 424-431. [CrossRef]

45. Kim, Y.; Cha, C.; Engesser, K.; Kim, S. Degradation of various alkyl ethers by alkyl ether-degrading Actinobacteria isolated from activated sludge of a mixed wastewater treatment. Chemosphere 2008, 73, 1442-1447. [CrossRef]

46. Liu, W.; Li, Y.; Liu, F.; Jiang, W.; Zhang, D.; Liang, J. Visible-light-driven photocatalytic degradation of diclofenac by carbon quantum dots modified porous g-C3N4: Mechanisms, degradation pathway and DFT calculation. Water Res. 2019, 151, 8-19. [CrossRef] [PubMed]

47. Jia, Y.; Tran, H.; Kim, D.; Oh, S.; Park, D.; Zhang, R.; Ahn, D. Simultaneous organics removal and bio-electrochemical denitrification in microbial fuel cells. Bioprocess Biosyst. Eng. 2008, 31, 315-321. [CrossRef]

48. Xu, K.; Ben, W.; Ling, W.; Zhang, Y.; Qu, J.; Qiang, Z. Impact of humic acid on the degradation of levofloxacin by aqueous permanganate: Kinetics and mechanism. Water Res. 2017, 123, 67-74. [CrossRef] 